\title{
炭素䋊維シートで補強した 鉄筋コンクリート橋脚の耐震性能
}

\author{
長田 光司 ${ }^{* 1} \cdot 大$ 野 晋也 ${ }^{* 2} \cdot$ 山口 隆裕 ${ }^{* 3} \cdot$ 池田 尚治*4
}

概 要 鉄筋コンクリート橋脚の鞅性向上に対する炭素繊維シートの巻立てによる補強効果および補強後の耐震性能の把握 を目的として, 矩形断面の実橋脚をモデル化した独立 1 本柱の供試体を用いて静的正負繰返し載荷実験と準動的載荷実験を 行った。実験結果から，炭素繊維シートによる補強が対象とした鉄筋コンクリート橋脚の変形性能の向上に有効であることを 確認するとともに, 必要な補強量と補強範囲を求めることができた。また, 带鉄筋方向のシートの破断は最初に柱断面コー ナー部で生じることが示された。準動的載荷実験の結果からは, 補強により対象とした鉄筋コンクリート橋脚は設計水平震度 の約 2 倍の加速度を持つ地震波に対して大きな耐力の低下など生じないことが示された。

キーワード : 耐震補強, 炭素繊維シート, 鉄筋コンクリート橋脚, 䩲性, 準動的載荷

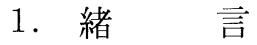

先般の兵庫県南部地震においては, せん断に対する計 算方法や鉄筋の引張部定着に関する規定の見直しが図ら れた 1980 年の示方書以前の規準を基にして設計, 施工 された鉄筋コンクリート橋脚に，特に大きな被害が生じ た。そのため, 補強が必要とされる橋脚に対して耐荷能 力の向上と共に変形性能の向上を目的とした補強が進め られている。

鉄筋コンクリート橋脚の補強工法としては, 主に RC 巻立て工法や鋼板巻立て工法が採用されているが, 新し い工法の一つとして施工性に優れ補強厚さが薄い炭素絨 維シート (以下, CFS と記す) を用いた巻立て工法が 注目されている。CFS は炭素繊維を構造物の補強に適 用することを目的として開発されたものであり， その開 発過程と特性については文献1）に簡潔に述べられてい る。CFS の鉄筋コンクリート構造への適用に当たり, これまでにせん断補強や主鉄筋の段落し部への補強など

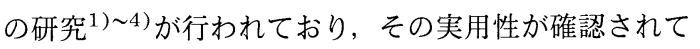
いる。実際に $\mathrm{RC}$ 箱桁橋の箱析部のせん断補強として 施工された例 ${ }^{5}$ もある。CFS の巻立て工法を鉄筋コン クリート橋脚の補強に本格的に取り入れていくのには, CFS の巻立てによりどの程度, 既存橋脚の変形能が改 良され靱性が向上するのか, また, 補強により耐震性能

\footnotetext{
*1 日本道路公団東京第一管理局（正会員）

*2 横浜国立大学大学院計画建設学専攻 (正会員)

*3 横浜国立大学助手 工学部建設学科 (正会員)

*4 横浜国立大学教授 工学部建設学科 (正会員)
}

はどのように改良されるのかについて検討し，これらの 点を明確にしておく必要がある。

本研究は，鉄筋コンクリート橋脚の鞄性向上に対する CFS の巻立てによる補強効果および補強後の耐震性能 の把握を目的として行った実験的研究であり，実橋脚を モデル化した独立 1 本柱の供試体を用いて静的正負繰返 し載荷実験と準動的載荷実験を行ったものである。ま た，準動的載荷システムに組入れた動的映像記録化シス テム ${ }^{6)}$ によって橋脚の動的応答挙動と破壊に至る過程を ビデオテープに記録し, 視覚面からも耐震性能について 検討することとした。

\section{2. 実験方法}

\section{1 供試体}

実験の対象とした既存の鉄筋コンクリート橋脚は, 1980 年以前の規準を基に設計, 施工された独立 2 本柱 形式および壁形式の中の代表的な寸法のもの（以下, 既 存橋脚と記す）とした。供試体の形状を図-1に, 諸元 と実験要因の一覧を表 -1 に示す。供試体の寸法は想定 した既存橋脚の約 $1 / 4$ スケールとし，引張鉄筋比および 帯鉄筋比を既存橋脚との対応を考え等しくした。ただ し, 帯鉄筋にはD D 6 鉄筋を用いたので, 柱の断面寸法 に対する配置間隔の比は供試体の方が大きくなってい る。このことより, 既存橋脚と供試体では, せん断ひび 割れの発生状況や主鉄筋の座屈時が若干異なる恐れがあ るが，破壊形態が変わることはないものと考えられる。 なお，実験の目的から，橋脚の勒性向上に対する CFS の補強効果を, より明確に把握することを考えて供試体 


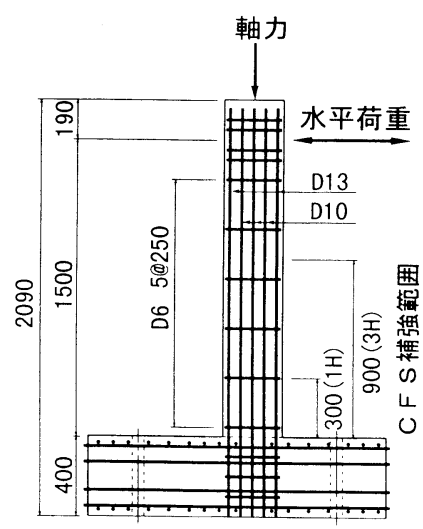

(北)

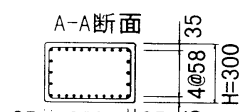

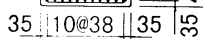
$B=450$

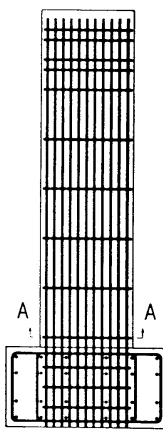

長短比 15 供試体
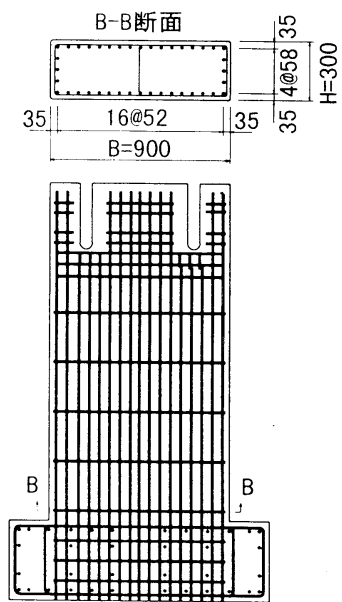

長短比3.0供試体

図-1 供試体の形状

表一1 供試体の諸元および実験要因

\begin{tabular}{|c|c|c|c|c|c|c|c|}
\hline No. & 供 試 体 名*1 & $\begin{array}{c}\text { 断面形状 } B \times H \\
(\mathrm{~mm})\end{array}$ & 帯 鉄 筋*2 & $\begin{array}{l}\text { 帯鉄筋方向 } \\
\text { 炭素繊維. }^{* 3}\end{array}$ & 主 鉄 筋*4 & $\begin{array}{l}\text { 主鉄筋方向 } \\
\text { 炭 素 繊 維 }\end{array}$ & 載荷方法*5 \\
\hline 1 & $\mathrm{ST}-\mathrm{N}-1.5$ & \multirow{9}{*}{$450 \times 300$} & \multirow{9}{*}{$\begin{array}{l}\text { D 6@250 } \\
(0.056 \%)\end{array}$} & $-(0 \%)$ & \multirow{9}{*}{$\begin{array}{c}22-\mathrm{D} 13 \\
6-\mathrm{D} 10 \\
(2.38 \%)\end{array}$} & - & \multirow{4}{*}{ 静 的 } \\
\hline 2 & $\mathrm{ST}-\mathrm{CF}-1.5$ & & & 1 層 $(0.05 \%)$ & & \multirow{3}{*}{$1 / 4$ 層 } & \\
\hline 3 & $\mathrm{ST}-2 \mathrm{CF}-1.5$ & & & 2 層 $(0.1 \%)$ & & & \\
\hline 4 & AST-CPB-1.5 & & & 2 層 $(0.1 \%)$ & & & \\
\hline 5 & APD $40-N-1.5$ & & & ( & & 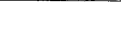 & \multirow{5}{*}{ 準動的 } \\
\hline 6 & $\mathrm{PD} 45-\mathrm{N}-1.5$ & & & $-(0 \%)$ & & - & \\
\hline 7 & PD 20-CP-1.5 & & & & & \multirow{3}{*}{$1 / 4$ 層 } & \\
\hline 8 & $\mathrm{APD} 40-\mathrm{CP}-1.5$ & & & 2 曽 $(0.1 \%)$ & & & \\
\hline 9 & $\mathrm{PD} 45-2 \mathrm{CF}-1.5$ & & & 2 層 $(0.1 \%)$ & & & \\
\hline 10 & $\mathrm{AST}-\mathrm{N}-3.0$ & \multirow{4}{*}{$900 \times 300$} & \multirow{4}{*}{$\begin{array}{l}\text { D 6@250 } \\
(0.028 \%)\end{array}$} & $-(0 \%)$ & \multirow{4}{*}{$\begin{array}{c}34-\mathrm{D} 13 \\
6-\mathrm{D} 10 \\
(1.76 \%)\end{array}$} & - & \multirow{2}{*}{ 静 的 } \\
\hline 11 & $\mathrm{AST}-\mathrm{CP}-3.0$ & & & 4 層 $(0.1 \%)$ & & $1 / 4$ 層 & \\
\hline 12 & $\mathrm{PD} 40-\mathrm{N}-3.0$ & & & $-(0 \%)$ & & - & \multirow{2}{*}{ 準動的 } \\
\hline 13 & $\mathrm{PD} 40-\mathrm{CP}-3.0$ & & & 4 層 $(0.1 \%)$ & & $1 / 4$ 層 & \\
\hline
\end{tabular}

$* 1:$ 放 $\bigcirc-\triangle-\square$

々[供試体グループ］

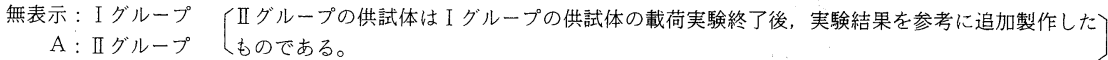

$O[$ 載荷方法 $]$

ST : 静的載荷実験

PD : 準動的載荷実験

(20: 作用地震波の最大加速度が $0.2 \mathrm{~g}$ 相当

40 ：" $400 \mathrm{gal}$ 相当

45：" $450 \mathrm{gal}$ 相当

$\Delta[$ 帯鉄筋方向補強量 $]$

$\mathrm{N}$ : 無補強

$\mathrm{CF}:$ フーチング天端から $3 H$ まで $p_{c f}=0.05 \%$

$2 \mathrm{CF}$ : $p_{c f}=0.1 \%$

$\mathrm{CP}$ ：" $\quad 1 H$ まで $p_{c f}=0.1 \%, 1 \mathrm{H}$ から $3 \mathrm{H}$ まで長短比 1.5 供試体は $p_{c f}=0.05 \%$, 長短比 3.0 供試体 は $p_{c f}=0.03 \%$

$B$ : 帯鉄筋方向の CFS の付着面積が $1 / 4$

$\square[$ 断面形状 $(B / H)]$

$* 2:(\quad)$ 内の值は帯鉄筋比

*3:( )内の值は CFS の面積比 $\left(p_{c f}\right)$ で次式により求めた。

$$
p_{c f}=2 t_{c f} / B \times 100(\%)
$$

$* 4:()$ 内の值は軸方向鉄筋比

*5: 軸圧縮応力は全供試体とも $0.59 \mathrm{MPa}$ とした。 
に主鉄筋の段落しは施していなく，段落し部の悪影響の 生ずる恐れのある既存橋脚とは異なったものとなってい る。

供試体の製作は 2 回に分けて行っており，コンクリー 卜の打設日は 2 力月程度異なっている。表-1に示す供 試体名の記号が A で始まるものが 2 回目に, その他が 1 回目に製作されたことを示している。以降，1回目に製 作された供試体をまとめて I グループ， 2 回目のものを IIグループと呼ぶ。IIグループの供試体は I グループの 供試体の載荷実験終了後, 実験結果を参考にして追加製 作されたものである。

供試体 No. 1 No. 9 は柱断面の幅と高さの比（以 下, 長短比と記す) を 1.5 とし, その内, No. 1 No. 4 は静的正負繰返し（以下, ST と記す）載荷を, No. 5 No. 9 は耐震性能を把握するために準動的（以下，PD と記す）載荷を行ったものである。供試体 No. 10 No. 13 は, 壁形式の橋脚を対象として長短比を 3.0 と したものであり, No. 10 と No. 11 は ST 載荷を, No. 13 と No. 14 には PD 載荷を行った。表に示す無補強の 供試体が既存橋脚に対応したものであり, CFS で補強 した供試体はそれぞれ CFS の補強量と補強範囲が異 なっている。供試体 No. 4, No. 7, No. 8, No. 11 と No. 13 の帯鉄筋方向の CFS の補強範囲は, 供試体 No. 1 No. 3 の実験終了後その結果を参考にして定めたも のであり, フーチング天端から $1 H(H:$ 柱断面高さ) までの範囲が重点的に補強されている。

CFS の絾維は一方向のみに配列されており, CFS に よる帯鉄筋方向の補強はせん断補強とコンクリートおよ び主鉄筋の拘束効果による橋脚の勒性向上を意図したも のである。また，主鉄筋方向の補強は，曲げひび割れに より帯鉄筋方向の CFS が損傷を受けるのを防止し, か つ帯鉄筋方向の CFS の応力伝達を滑らかに行うことを 意図している。経済性および施工性を考慮して, 既存橋 脚での帯鉄筋方向の補強量は, 面積比で $0.05 \sim 0.1 \%$ 程 度と考えられている。これは, 長短比 1.5 の供試体レベ ルで 1 2 層の補強層数, 3.0 の供試体で $2 \sim 4$ 層の補強 層数となり, 本実験での供試体の帯鉄筋方向の補強層数 はこれらに対応するものとした。

供試体 AST-CPB-1.5 は, 既存橋脚での CFS とコ ンクリートとの付着力を想定して, 供試体での 1 層の補 強が実構造物の 4 層に対応することから CFS とコンク リートの付着面積を $1 / 4$ としたものである。付着面積の 調整は，貼付面と帯鉄筋方向との CFS との間に, 20 $\mathrm{mm} \times 20 \mathrm{~mm}$ の碁盤目状に区切りその目の 4 個に 1 個 を切り取ったフィルムを挟み，そこだけを付着面とする ことにより行った。

今回, 主鉄筋の段落しは設けていないので, 供試体で
の主鉄筋方向の CFS の補強は，既存橋脚で 1 層接着す ることを想定し CFS を $10 \mathrm{~mm}$ 幅の帯状にして 40 $\mathrm{mm}$ ピッチで接着することとし, 面積比を合わせた。 CFS による補強範囲は, フーチング天端から $3 H$ の範 囲までとし，带鉄筋方向の 2 層目以降は供試体によって $3 H$ の範囲までと $1 H$ までの場合とで異なったものと なっている。

CFS の接着は, 下地処理, プライマーの塗布, 主鉄 筋方向への CFS の貼付, 樹脂の含浸, 帯鉄筋方向への CFS の貼付, 樹脂の含浸の順に行った。貼付における CFS のラップ長については, CFS 同士の重ね合わせに よる付着試験の結果から, 少なくとも $40 \mathrm{~mm}$ あれば素 材強度を確保できることが示されているので7), 安全を 見て $100 \mathrm{~mm}$ とした。また, 柱断面のコーナー部は, CFS への局部応力を緩和するために面取りを行ってい るが, その曲面の半径は, CFS の曲率半径の大きさと 引張強度の関係を求めた試験における, 最小曲率半径は $10 \mathrm{~mm}$ 以上が望ましいという結果から判断して 30 $\mathrm{mm}$ とした。

\section{2 使用材料}

使用したCFS は, シート状の炭素緘維材にエポキシ 樹脂を施工時に含浸させたものである。ここで用いた炭 素繊維材は, 籠目状に編まれた糸上に炭素緎維が一方向 に一様に配列されたものを台紙を介してロール状に巻い たものであり，その特性を表-2に示す。貼付けおよび 含浸に使用したエポキシ樹脂は, 粘度や硬化時間などに より春秋 (標準) 用, 夏用, 冬用の 3 タイプに分かれて いる。Iグループの供試体に対しては標準用を，II グ ループには冬用を用いた。樹脂自体の硬化後の引張強度 は，およそ $45 \mathrm{MPa}$ となっている。

供試体に使用した鉄筋の力学的特性を表-3に, 橋脚 供試体と同様に養生したコンクリート円柱供試体の載荷 実験時における力学的特性を表-4に示す。主鉄筋に使 用した D 13 鉄筋の強度およびコンクリート強度とも II グループに使用した方が I グループのものより若干大き な值を示している。なお，使用した骨材の最大寸法は 10 $\mathrm{mm}$ とした。

\section{3 載荷方法}

ST 載荷および PD 載荷には, 図-1 に示すように共 に2 本のアクチュエーターを使用し, 柱頭部に一定の軸 圧縮力を載荷しながら水平力を作用させた。供試体は フーチング部を $\mathrm{PC}$ 鋼棒で反力床に固定した。軸圧縮応 力は上部構造の重さを考慮して全供試体とも同じ 0.59 $\mathrm{MPa}$ とした。載荷方向は, 図-1に示す南北方向とな る橋軸方向とした。以降, 北側へ押しの荷重および変位 を正 $(+)$ の符号で, 南側への引きの荷重および変位を 負 $(-)$ の符号で示す。 
$\mathrm{ST}$ 載荷の方法は計算降伏荷重載荷時に得られた変位 の正負の平均值を $1 \delta_{y}$ として, 変位を $1 \delta_{y}$ ずつ増加さ せながら，載荷終了まで各変位段階で 1 回の正負載荷を 行うのを基準とした。同じ変位での繰返し回数を 1 回と したのは, 実際の大地震に構造物に生じる大きな変形の

表-2 炭素繊維シートの力学的特性

\begin{tabular}{|c|c|c|c|c|}
\hline $\begin{array}{c}\text { 設計厚み } \\
(\mathrm{mm})\end{array}$ & $\begin{array}{c}\text { 繊維目付量 } \\
\left(\mathrm{g} / \mathrm{m}^{2}\right)\end{array}$ & $\begin{array}{c}\text { 引張強度 }{ }^{* 1} \\
(\mathrm{MPa})\end{array}$ & $\begin{array}{c}\text { 弾性係数*1 } \\
\text { (GPa) }\end{array}$ & 適用供試体 ${ }^{* 2}$ \\
\hline 0.110 & 200 & 4220 & 243 & I グループ \\
\hline 0.110 & 201 & 4047 & 252 & II グループ \\
\hline
\end{tabular}

表-3 鉄筋の力学的特性

\begin{tabular}{|c|c|c|c|c|c|c|}
\hline 種 & 類 & 降伏強度 & 引張強度 & 弹性係数 & 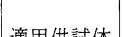 & \\
\hline 呼び径 & 規 格 & (MPa) & $(\mathrm{MPa})$ & (GPa) & 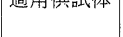 & 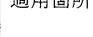 \\
\hline D 6 & SD 295 & 360 & 530 & 175 & \multirow{3}{*}{ I グループ } & 帯 鉄 筋 \\
\hline D 10 & SD 295 & 350 & 500 & 172 & & 側方鉄筋 \\
\hline D 13 & SD 345 & 380 & 560 & 172 & & 主 鉄 筋 \\
\hline D 6 & SD 295 & 340 & 560 & 187 & \multirow{3}{*}{ II グループ } & 帯 鉄 筋 \\
\hline D 10 & SD 295 & 360 & 530 & 168 & & 側方鉄筋 \\
\hline D 13 & SD 345 & 390 & 570 & 172 & & 主 鉄 筋 \\
\hline
\end{tabular}

表-4 コンクリートの力学的特性

\begin{tabular}{c|c|c|c|c|c}
\hline $\begin{array}{c}\text { 王縮強度 } \\
(\mathrm{MPa})\end{array}$ & $\begin{array}{c}\text { 引張強度 } \\
(\mathrm{MPa})\end{array}$ & $\begin{array}{c}\text { 弾性係数 } \\
(\mathrm{GPa})\end{array}$ & ポアソン比 & $\begin{array}{c}\text { 材歯 } \\
(\text { 日) }\end{array}$ & 適用供試体 \\
\hline 27 & 2.5 & 18 & 0.20 & 50 & $\begin{array}{l}\mathrm{PD} 40-\mathrm{N}-3.0 \\
\text { 除く グループ }\end{array}$ \\
\hline 31 & 2.2 & 18 & 0.20 & 42 & $\mathrm{PD} 40-\mathrm{N}-3.0$ \\
\hline 32 & 2.7 & 20 & 0.20 & 66 & I グループ \\
\hline
\end{tabular}

繰返し回数は，これまでの数多くのPD 実験の結果か ら多くても 1 回程度と考えられるからである。長短比 1.5 と 3.0 の両方の場合とも, 載荷は無補強の供試体よ り行い, CFSにより補強した供試体の降伏変位は無補 強の供試体の值とした。なお，計算降伏荷重は引張主鉄 筋が計算上降伏ひずみに達するときの值であり，柱基部 の回転の影響之部材の 2 次元的大きさを考慮し, 柱の固 定端をフーチング天端から $H / 2$ だけ下に仮定し, 反力 点をフーチング天端から $H / 4$ だけ上に仮定した棒部材 に供試体をモデル化し ${ }^{8)}$ ，材料の非線形を考慮して断面 をファイバー状に一次元的にモデル化（以下，ファイ バーモデルと記す）して求めたものである。

PD 実験に用いた初期設定值を表 -5 に示す。使用し た地震波は，兵庫県南部地震で神戸海洋気象台において 観測された NS 成分の 15 秒間とした。入力波は最大加 速度の生起時刻が 2.55 秒となるように初期微動を省略 し，加速度の大きさを調整したものである。PD 実験で の振動方程式の解は中央差分法によって求め, その時間 間隔は解の精度から 0.01 秒とした。したがって, 実験 では 15 秒間で 1500 ステップの繰返し載荷を行ってい る。固有周期は想定する既存橋脚より 0.3 秒とした。仮 想質量を求める際に必要な剛性としては, ひび割れ発生 前の初期剛性を用いた。仮想質量は部材を 1 自由度系と 仮定して, 固有周期と初期剛性を用いて計算した值であ る。減衰定数 $(h)$ は既往の研究 ${ }^{9)}$ より主鉄筋が降伏する 前は 0.03 とし, 降伏後は 0 とした。

入力波の最大加速度の大きさは, 表- 5 に示す值とし た。(1)と(2)はそれぞれ載荷 1 回目と 2 回目を示してお り, 2 回目の載荷は 1 回目終了後同じ供試体に対して 行ったものである。表に示す $0.2 \mathrm{~g}$ 相当の加速度とは,

表-5 準動的載荷実験に用いた初期設定値

\begin{tabular}{|c|c|c|c|c|c|c|c|}
\hline 供 試 体 名 & $\begin{array}{c}\text { 固 有 周 期 } \\
\text { (s) }\end{array}$ & $\begin{array}{c}\text { 初 期 剛 性 } \\
(\mathrm{MN} / \mathrm{m})\end{array}$ & $\begin{array}{c}\text { 仮想質量 } \\
(\mathrm{t})\end{array}$ & 減衰定数*1 & $\begin{array}{c}\text { 降伏変位*2 } \\
(\mathrm{mm})\end{array}$ & 加速度レベル*3 & $\begin{array}{c}\text { 最大加速度*3 } \\
\left(\mathrm{cm} / \mathrm{s}^{2}\right)\end{array}$ \\
\hline APD $40-N-1.5$ & \multirow{7}{*}{0.3} & \multirow{5}{*}{18.6} & \multirow{5}{*}{42} & \multirow{7}{*}{0.03} & \multirow{5}{*}{13.9} & $\begin{array}{l}\text { (1) } 400 \mathrm{gal} \text { 相当 } \\
\text { (2) } 400 \mathrm{gal} \text { 相当 }\end{array}$ & $\begin{array}{l}298 \\
298\end{array}$ \\
\hline $\mathrm{PD} 45-\mathrm{N}-1.5$ & & & & & & $\begin{array}{l}\text { (1) } 0.2 \mathrm{~g} \text { 相当 } \\
\text { (2) } 450 \mathrm{gal} \text { 相当 }\end{array}$ & $\begin{array}{l}146 \\
335\end{array}$ \\
\hline PD 20-CP-1.5 & & & & & & (1) $0.2 \mathrm{~g}$ 相当 & 146 \\
\hline APD $40-C P-1.5$ & & & & & & $\begin{array}{l}\text { (1) } 400 \mathrm{gal} \text { 相当 } \\
\text { (2) } 400 \mathrm{gal} \text { 相当 }\end{array}$ & $\begin{array}{l}298 \\
298\end{array}$ \\
\hline PD $45-2$ CF -1.5 & & & & & & $\begin{array}{l}\text { (1) } 0.2 \mathrm{~g} \text { 相当 } \\
\text { (2) } 450 \mathrm{gal} \text { 相当 }\end{array}$ & $\begin{array}{l}146 \\
335\end{array}$ \\
\hline PD $40-N-3.0$ & & \multirow[t]{2}{*}{24.5} & \multirow{2}{*}{56} & & \multirow{2}{*}{12} & $\begin{array}{l}\text { (1) } 0.2 \mathrm{~g} \text { 相当 } \\
\text { (2) } 400 \mathrm{gal} \text { 相当 }\end{array}$ & $\begin{array}{l}170 \\
346\end{array}$ \\
\hline $\mathrm{PD} 40-\mathrm{CP}-3.0$ & & & & & & $\begin{array}{l}\text { (1) } 0.2 \mathrm{~g} \text { 相当 } \\
\text { (2) } 400 \mathrm{gal} \text { 相当 }\end{array}$ & $\begin{array}{l}170 \\
346\end{array}$ \\
\hline
\end{tabular}

$* 1:$ 減衰定数 $(h)$ は, 主鉄筋降伏後は $h=0$ とする。

*2: 長短比が 1.5 の供試体の降伏变位は, ST-N-1.5 の静的載荷実験の結果, 3.0 の供試体の降伏変位はファイバーモデルの計算結果。

*3: 上段(1)が 1 ケース目，下段(2が 2 ケース目を表す。 
主鉄筋の応力がファイバーモデルでの計算上 $294 \mathrm{MPa}$ となる時の荷重と仮想質量を用いて求めた加速度を，道 路橋示方書 ${ }^{10)}$ に規定されている応答を考慮した固有周 期別補正值の 1.25 で除し， その值を実橋の設計上での $0.2 \mathrm{~g}$ に相当する地盤加速度である之考えたもので, こ れにより, 実構造物と対応させている。400 gal 相当お よび $450 \mathrm{gal}$ 相当の加速度は, それぞれ $0.2 \mathrm{~g}$ 相当の加 速度との比例計算により求めたものである。

\section{4 計測方法}

柱のフーチングとの相対変位の計測箇所は, 水平力の 載荷点之同じ高さのフーチング天端から $1500 \mathrm{~mm}$ の 位置, その $1 / 2$ の $750 \mathrm{~mm}$, 天端より $50 \mathrm{~mm}$ の位置の 3 箇所とし, 以降に示す変位の值は載荷点での值とす る。歪の測定は, 主鉄筋と帯鉄筋の適当な箇所に歪ゲー ジを貼付して行った。また, CFS の拘束効果をみるた めにコンクリートおよび CFS の表面にも歪ゲージを貼 付して測定した。ひび割れの計測は図-1に示す西面で 行った。

$\mathrm{PD}$ 実験におけるビデオでの映像の記録は, 地震波の 生起時刻の 0.03 秒毎に行い, 一静止画の録画時間を 1 フレーム $(1 / 30$ 秒) とした。この場合, 地震波デー夕の 時間 15 秒に対して総録画時間は約 16.7 秒となる予定 で, ビデオテープの標準再生によって得られる画像でほ ぼ実時間スケールとなる。また, ビデオカメラを 2 台使 用し, 1 台は供試体全体の挙動を, 他の 1 台は柱付け根 の高さ $1.5 H$ の範囲のみを撮影した。

\section{ST 載荷実験の結果と考察}

\section{1 耐荷挙動と勒性}

実験結果を表-6 に示す。無補強の供試体 ST- $\mathrm{N}-1.5$ の降伏変位 $\left(\delta_{y}\right)$ は $13.9 \mathrm{~mm}, \mathrm{AST}-\mathrm{N}-3.0$ の降伏変位 $\left(\delta_{y}{ }^{\prime}\right)$ は $12.2 \mathrm{~mm}$ となり, アクチュエーターのスト
ロークの制限上, 各供試体の載荷最大変位は降伏変位の 7〜8 倍程度となった。

供試体 $\mathrm{ST}-\mathrm{N}-1.5, \mathrm{ST}-\mathrm{CF}-1.5$ と $\mathrm{ST}-2 \mathrm{CF}-1.5$ の 実験より得られた荷重一変位曲線の包絡線とファイバー モデルによる計算值を図-2 に示す。ただし, 計算値は $\mathrm{ST}-\mathrm{N}-1.5$ に一方向の漸増載荷を行ったものとし, コ ンクリートの压縮歪が 5000 亿に達するときまでの值で ある。計算值は実験值と良く一致し区別がつかない。縦 軸と横軸の值は $\mathrm{ST}-\mathrm{N}-1.5$ の計算降伏荷重と降伏変位 で除し無次元化した值を示す。

供試体 ST-N-1.5 は, $4 \delta_{y}$ 付近で斜めひび割れが大 きく伸展し, 主鉄筋の座屈やかぶりコンクリートの荆離 が生じ耐力が低下した。 $-7 \delta_{y}$ 載荷時には残存耐力は 16 $\mathrm{kN}$ となり, ほとんど水平耐力のない状態となった。破 壊は広い範囲にわたっており, フーチング天端から約 3 $H$ の高さまで主鉄筋に沿った縦方向の大きなひび割れ がみられた。1Hの高さの範囲では帯鉄筋内部のコンク リートまで破壊していた。帯鉄筋方向の CFS の補強量 が 1 層である供試体 $\mathrm{ST}-\mathrm{CF}-1.5$ は, $-5 \delta_{y}$ 載荷途中で フーチング天端から $1 H$ の高さの範囲で圧縮側の CFS が脵らみだし，耐力の低下がみられた。この時点で主鉄

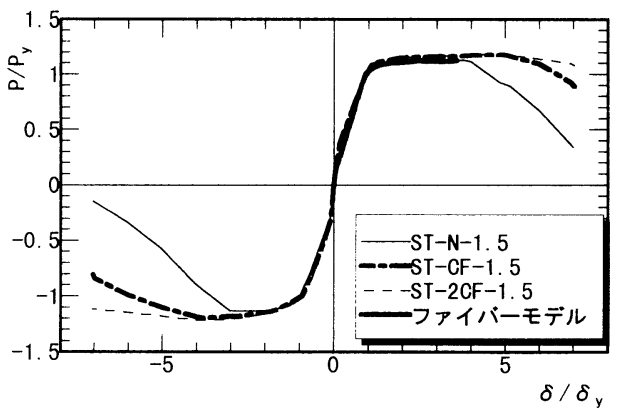

図-2 荷重-変位の包絡線

\section{表-6 静的正負繰返し載荷実験結果}

\begin{tabular}{|c|c|c|c|c|c|}
\hline 供試体 名 & 最 終 載 荷 & 最大耐力 $* 1$ & 残存耐力*2 & 靯性率 & 備 \\
\hline $\mathrm{ST}-\mathrm{N}-1.5$ & $\pm 7 \delta_{y}$ & $\begin{array}{l}+110 \mathrm{kN} \\
-111 \mathrm{kN}\end{array}$ & $\begin{array}{l}+33 \mathrm{kN}(30 \%) \\
-16 \mathrm{kN}(14 \%)\end{array}$ & 3 & $\begin{array}{l}\cdot-4 \delta_{y} \text { 載荷途中で主鉄筋が座屈, かぶりコンクリートが剥離 } \\
\cdot \text { •広い範囲でのひび割れ }\end{array}$ \\
\hline $\mathrm{ST}-\mathrm{CF}-1.5$ & $\pm 7 \delta_{y}$ & $\begin{array}{l}+115 \mathrm{kN} \\
-118 \mathrm{kN}\end{array}$ & $\begin{array}{l}+86 \mathrm{kN}(75 \%) \\
-82 \mathrm{kN}(70 \%)\end{array}$ & 5 & $\begin{array}{l}\cdot-5 \delta_{y} \text { 載荷途中で基部から } 1 H \text { の範囲の CFS が膨らみだす } \\
\cdot-6 \delta_{y} \text { 䡛荷途中, CFS が破断 }\end{array}$ \\
\hline $\mathrm{ST}-2 \mathrm{CF}-1.5$ & $\pm 7 \delta_{y}$ を 5 回 & $\begin{array}{l}+116 \mathrm{kN} \\
-118 \mathrm{kN}\end{array}$ & $\begin{array}{l}+106 \mathrm{kN}(92 \%) \\
-109 \mathrm{kN}(93 \%)\end{array}$ & 7 以上 & $\begin{array}{l}\cdot-5 \delta_{y} \text { 載荷途中で基部から } 1 H \text { の範囲の CFS が膨らみだす } \\
\cdot-7 \delta_{y}(1 \text { 回目) 載荷途中で CFS 同士のラップ長部分がはがれる } \\
\cdot-7 \delta_{y}(5 \text { 回目) 載荷時に主鉄筋方向の CFS が破断 } \\
\end{array}$ \\
\hline $\mathrm{AST}-\mathrm{CPB}-1.5$ & $\begin{array}{c} \pm 6.9 \delta_{y} \text { を } 5 \text { 回 } \\
\left(+8 \delta_{y} \text { 途中で終了 }\right) \\
\end{array}$ & $\begin{array}{l}+120 \mathrm{kN} \\
-121 \mathrm{kN}\end{array}$ & $\begin{array}{l}+112 \mathrm{kN}(93 \%) \\
-112 \mathrm{kN}(93 \%)\end{array}$ & 7 以上 & $\begin{array}{l}\cdot-5 \delta_{y} \text { 載荷途中で基部から } 1 \mathrm{H} \text { の範囲の CFS が膨らみだす } \\
\cdot-6.9 \delta_{y} \text { (1 回目) 載荷途中で CFS が破断 }\end{array}$ \\
\hline $\mathrm{AST}-\mathrm{N}-3.0$ & $\pm 7 \delta_{y}$ & $\begin{array}{l}+179 \mathrm{kN} \\
-176 \mathrm{kN}\end{array}$ & $\begin{array}{l}+92 \mathrm{kN}(51 \%) \\
-108 \mathrm{kN}(61 \%)\end{array}$ & 4 & $\cdot-5 \delta_{y}$ 載荷途中で主鉄筋が座屈, かぶりコンクリートが剥離 \\
\hline $\mathrm{AST}-\mathrm{CP}-3.0$ & $\pm 7.8 \delta_{y}$ & $\begin{array}{l}+185 \mathrm{kN} \\
-183 \mathrm{kN}\end{array}$ & $\begin{array}{l}+157 \mathrm{kN}(85 \%) \\
-158 \mathrm{kN}(86 \%)\end{array}$ & 7 以上 & $\begin{array}{l}\cdot-5 \delta_{y} \text { 載荷途中で基部から } 1 H \text { の範囲の CFS が膨らみだす } \\
\cdot \text { CFS の破断等は見られない }\end{array}$ \\
\hline
\end{tabular}

$* 1:$ 上段は正側の，下段は負側の最大耐力をそれぞれ示す。

$* 2$ : 載荷を終了する変位段階の 1 回目における残存耐力を示す。（）内の值は，最大耐力に対する比率を表す。 
筋の座屈が生じたものと考えられる。 $-6 \delta_{y}$ 時には脵ら みだした部分の帯鉄筋方向の CFS が大きな音とともに 柱コーナー部付近から破断した。この時, 主鉄筋方向の CFS も破断した。補強量が 2 層である $\mathrm{ST}-2 \mathrm{CF}-1.5$ は $-7 \delta_{y}$ 載荷時まで明確な耐力の低下はみられなかっ たので $7 \delta_{y}$ の正負載荷を 5 回行い載荷を終了した。 1 回 目の繰返し載荷時の残存耐力は最大耐力の $93 \%$ となり, う回目載荷時においてもまだ $70 \%$ を保持していた。損 傷範囲は供試体 $\mathrm{ST}-\mathrm{CF}-1.5$ と同様にフーチング天端 から $1 H$ の高さに集中し, $-5 \delta_{y}$ 時には CFS がわずか に膨らみだした。 $-7 \delta_{y}$ の 1 回目の載荷時には CFS 同 士のラップ長部分がはがれ, $7 \delta_{y} 5$ 回の載荷で主鉄筋方 向の CFS が破断し, ラップ長部の CFS の損傷も進ん だ。ラップ長はもう少し長い方が好ましいと思われた。 長短比が 1.5 の場合, CFS で補強したことにより, 主 鉄筋の座屈時点が無補強のものより $1 \delta_{y}$ 程度大きな変 形時となり, 補強量としては面積比で $0.1 \%$ とすること により, $7 \delta_{y}$ の変形時においても大きな耐力の低下の生 じないことが確認できた。また，補強範囲としてはフー チング天端から $1 H$ の高さの範囲が重要であることが 示された。写真 -1 に $-7 \delta_{y}$ 載荷時の状況を示すが, CFSの補強の有無により外見の損傷の程度がかなり異 なっており, 橋脚の健全性を保つ上での CFS の補強効 果がよくわかる。

長短比 3.0 の場合の荷重 - 変位曲線の関係を 1.5 の場 合と同様に図-3 に示す。長短比が 3.0 と大きい場合, 計算降伏荷重は正側の包絡線上での降伏荷重より約 10 \%小さい值を示し，負側の実験值とほぼ対応する結果 となっている。なお，計算降伏荷重時における柱付け根 の主鉄筋の引張歪は正負とも $1900 \sim 2000 \mu$ とほぼ降伏 歪に達していた。

無補強の供試体 AST-N-3.0 は, $4 \delta_{y}^{\prime}$ 載荷時に斜め ひび割れが大きく伸展し, $-5 \delta_{y}{ }^{\prime}$ 載荷時に圧縮部のすべ ての主鉄筋の座屈とともに柱の全幅にわたって高さ 1.5 $H$ の範囲でコンクリートの䟝離が生じ, 耐力が最大時

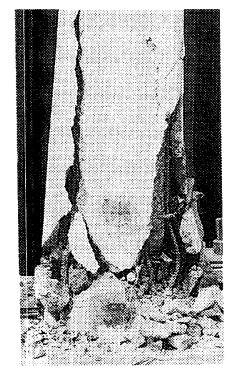

$\mathrm{ST}-\mathrm{N}-1.5$

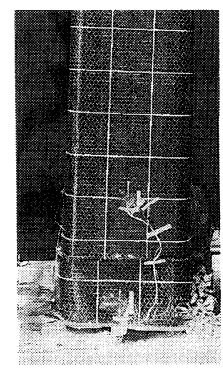

$\mathrm{ST}-\mathrm{CF}-1.5$

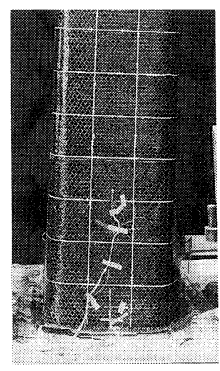

ST-2CF-1. 5
写真-1 $-7 \delta y$ 載荷時の状況（長短比 1.5 供試体）
の $84 \%$ に低下した。 $7 \delta_{y}{ }^{\prime}$ 載荷時の残存耐力は最大時の $50 \%$ となった。供試体 AST-CP-3.0 は，補強により 主鉄笳の座屈時点が長短比 1.5 の場合のように大きな変 形時の方にずれることはなく, 無補強の場合と同様に $-5 \delta_{y}{ }^{\prime}$ 載荷時に座屈が生じ，大きな音とともに CFS の 膨らみが観察された。しかしながら, 耐力の低下は小さ く最大時の 95\%を保持していた。CFS の補強量は, フーチング天端より 1 Hの高さまでのみ多くして $0.1 \%$ としたものであるが, $7 \delta_{y}{ }^{\prime}$ 載荷時においても CFS の破 断はみられず, 耐力は最大時の $87 \%$ を保っていた。

写真 $-2 に-7 \delta_{y}{ }^{\prime}$ 時の状況を示すが, 長短比 1.5 の場 合と同様外見の損傷の程度は CFS の有無でかなり異 なったものとなっている。

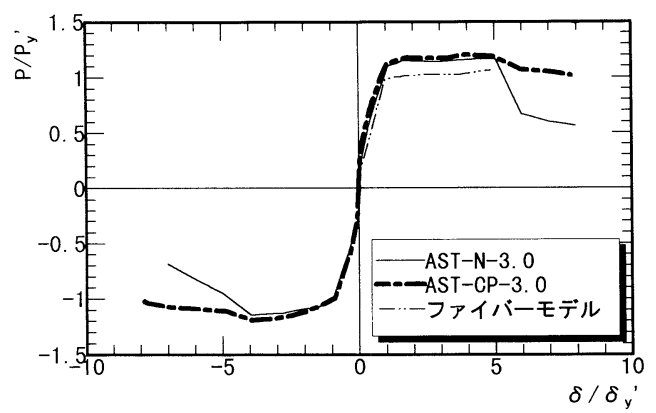

図-3 荷重一変位の包絡線

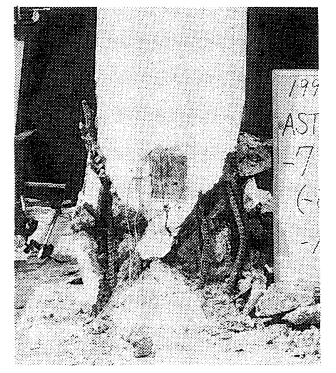

AST-N-3. 0

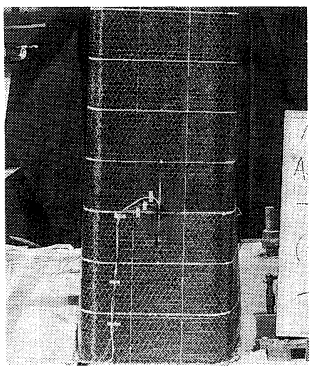

AST-CP-3. 0
写真 $-2-7 \delta y$ 載荷時の状況（長短比 3.0 供試体）

$: \mathrm{mm}$

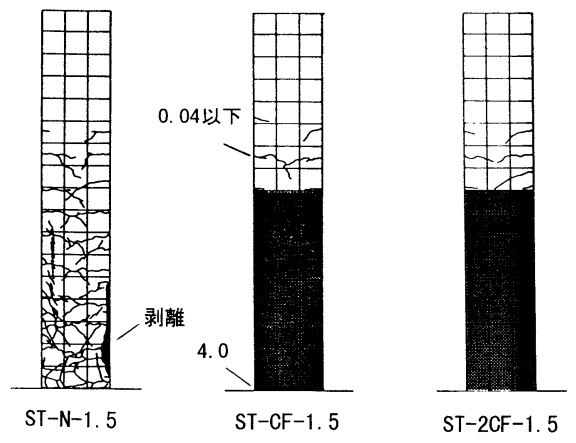

図-4 ひび割れ発生状況 $\left(-4 \delta_{y}\right.$ 時) 


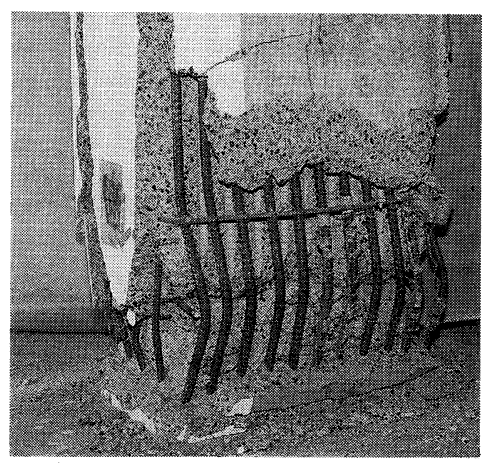

$\mathrm{ST}-\mathrm{N}-1.5$

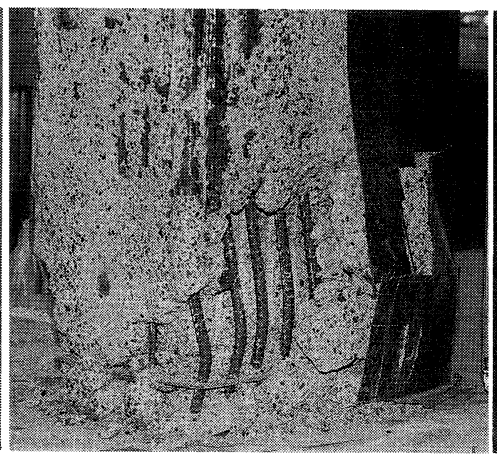

ST-GF-1. 5

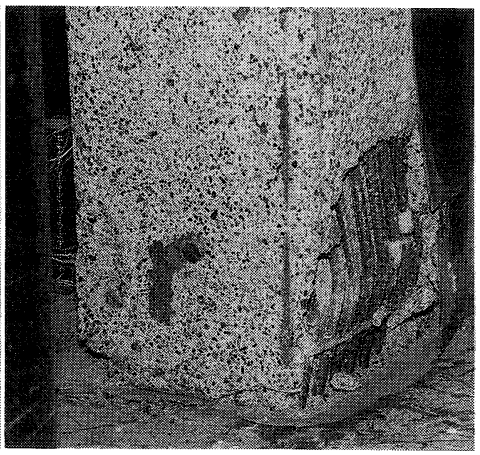

ST-2CF-1. 5

写真 -3 載荷終了後の柱付け根部の状況（長短比 1.5 供試体）

各供試体の終局変位を荷重一変位曲線上の計算降伏荷 重を下回らない最大変位とし, その值を長短比 1.5 の場 合は $\delta_{y}$ で, 3.0 の場合は $\delta_{y}$ 'で除した值をそれぞれの供 試体の勒性率とすると, 無補強の ST-N-1.5 と AST$\mathrm{N}-3.0$ はそれぞれ 3 と $4,0.05 \%$ 補強の $\mathrm{ST}-\mathrm{CF}-1.5$ は $5,0.1 \%$ 補強の $\mathrm{ST}-2 \mathrm{CF}-1.5$ と AST-CP-3.0 はそれ ぞれ 7 以上となった。なお, 補強の有無による耐力の差 は最大で 7\%であり, 主鉄筋方向の CFS による曲げ耐 力の向上はわずかであった。

\section{2 ひび割れ発生状況と柱付け根部の損傷状況}

図-4 に供試体 $\mathrm{ST}-\mathrm{N}-1.5, \mathrm{ST}-\mathrm{CF}-1.5$ と $\mathrm{ST}-2$ $\mathrm{CF}-1.5$ の $-4 \delta_{y}$ 時におけるひび割れ発生状況を示す。 $-4 \delta_{y}$ 時では, CFS で補強した供試体においては主鉄筋 の座屈による CFS の膨らみは生じておらず，ひび割れ も柱付け根および CFS の補強が途切れた高さ $3 H$ 付近 に若干みられる程度で, CFS には外見上変化は確認で きない。供試体 $\mathrm{ST}-\mathrm{CF}-1.5$ の場合, 最大ひび割れ幅 は, 付け根で $4.0 \mathrm{~mm}, 3 H$ 付近で $0.04 \mathrm{~mm}$ 以下とひ び割れが付け根に集中しているのがよくわかる。無補強 の $\mathrm{ST}-\mathrm{N}-1.5$ は $-4 \delta_{y}$ 時ですでに圧縮部の主鉄筋は座 屈し, コンクリートが大きく剝離しており, 引張側主鉄 筋に沿っては何本かの付着破壊によると思われるひび割 れが発生している。ひび割れは柱全体にわたり広い範囲 で生じている。写真-3に載荷終了後にコンクリートの 瓦磁を取り除き, CFS で補強していた供試体について は, 柱の北面の中心から南面の中心までの半周に当たる 分の CFS を㓦がし取った後の付け根部の状況を示す。 この写真から, 無補強の ST-N-1.5 は全周の主鉄筋が 座屈しているのに対し, CFS で補強することによりせ ん断破壊が防止され, 損傷範囲が小さく限定されている 様子がよくわかる。特に, 面積比で $0.1 \%$ の補強した ST-2 CF-1.5 はせん断による損傷を全く受けていない ことが示されている。

図-5 に供試体 AST-N-3.0 の -4 $\delta_{y}^{\prime}$ 時と AST-

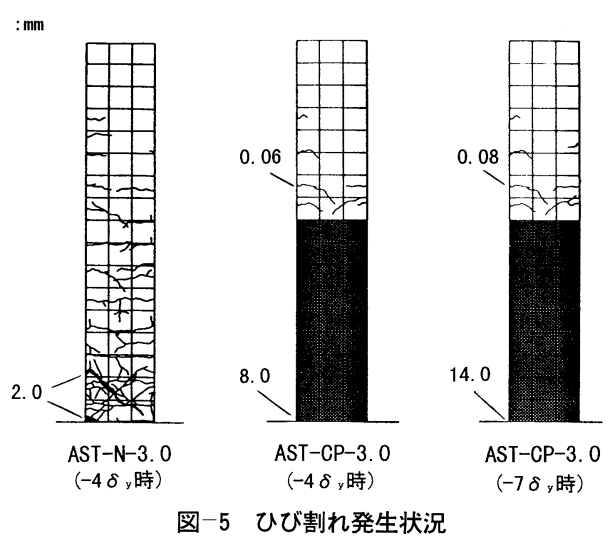

$\mathrm{CP}-3.0$ の $-4 \delta_{y}{ }^{\prime}$ 時および $-7 \delta_{y}{ }^{\prime}$ 時のひび割れ発生状 況を示す。 $-4 \delta_{y}$ ' 時では両供試体とも主鉄筋の座屈は 生じておらず, 無補強の AST-N-3.0 の場合, 幅が広 く目立つひび割れは柱付け根部に集中しており, 大きな 斜めひび割れもみられる。ひび割れの最大幅は, 付け根 の曲げひび割れが $2.0 \mathrm{~mm}$, 斜めひび割れが $2.0 \mathrm{~mm}$ で あった。 $-7 \delta_{y}{ }^{\prime}$ 時のひび割れ幅は, コンクリートの崩 壊のため測定不能となった。補強した AST-CP-3.0の $-4 \delta_{y}{ }^{\prime}$ 時のひび割れ発生状況は長短比 1.5 の場合之同様 であり, CFS には外見上全く変化はみられずひび割れ は柱付け根と CFS が途切れた高さ $3 H$ 付近のみに発生 していた。最大ひび割れ幅は付け根で $8.0 \mathrm{~mm}, 3 H$ 付 近で $0.06 \mathrm{~mm}$ であった。 $-7 \delta y$ 時には主鉄筋が座屈し ており,ひび割れ幅はそれぞれ $14.0 \mathrm{~mm}$ と $0.08 \mathrm{~mm}$ になった。写真 -4 に実験後の柱付け根部の状況を示 す。AST-N-3.0における全周の主鉄筋が座屈してい る様子や補強した AST-CP-3.0における CFS の膨ら んでいる様子がよくわかる。

\subsection{CFS とコンクリートの付着の影響}

供試体 $\mathrm{ST}-2 \mathrm{CF}-1.5$ および帯鉄筋方向の CFS とコ ンクリートの付着面積を $1 / 4$ とした $\mathrm{AST}-\mathrm{CPB}-1.5$ の 


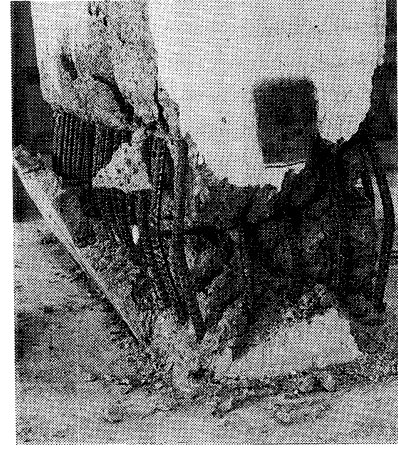

AST-N-3. 0

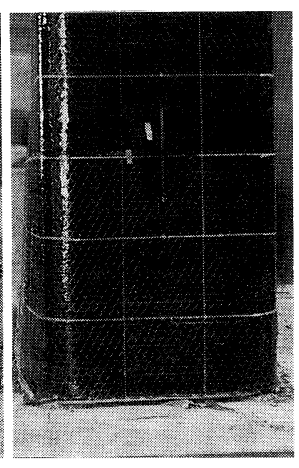

AST-CP-3. 0
写真-4 載荷終了後の柱付け根部の状況（長短比 3.0 供試体）

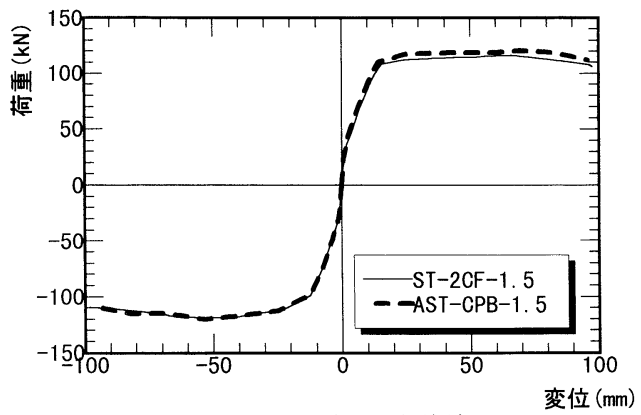

図-6 荷重-変位の包絡線

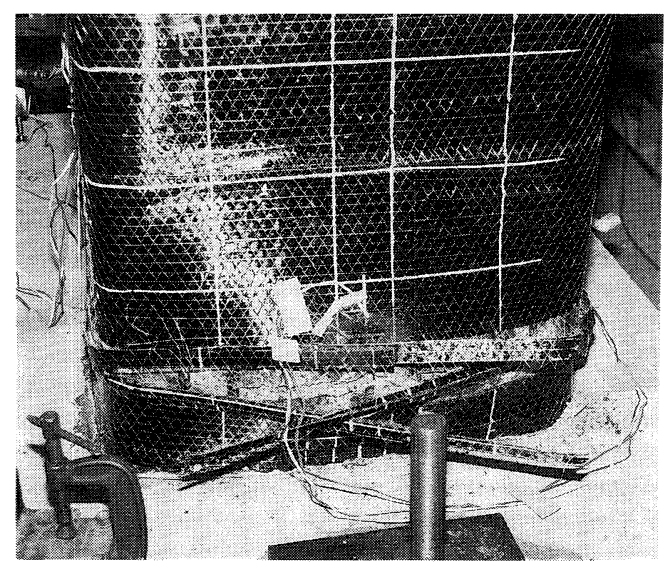

AST-CPB-1. 5

写真 $-5-6.9 \boldsymbol{\delta}_{y}(5$ 回目) 載荷時の南面（圧縮側）の状況

実験より得られた荷重一変位曲線の包絡線の比較を図-6 に示す。用いた主鉄筋の降伏強度が若干異なるため最大 耐力に $3 \%$ の差があるが, 包絡線の形状はほとんど一致 しているとみて良い。この結果は, CFS とコンクリー トとの付着力の変動が部材の耐荷挙動にほとんど影響し ないことを示しており, 実構造物においても, 供試体で の結果と同様にCFS の補強による勒性の向上は期待で きるものと考えられる。2 体の挙動において異なった点
は, 大変形時における CFS の損傷状況であった。 ST-2 CF-1.5 においては CFS は最終的に CFS 同土 のラップ長部で剝がれたが, AST-CPB-1.5 では帯鉄 筋方向の CFS が何力所かで破断した。この差が付着性 状の差により生じたものなのか，または，単なる実験誤 差なのかは今回の実験だけで判断することは困難であっ た。写真 -5 に AST-CPB-1.5 における $-6.9 \delta_{y}$ の 5 回目載荷時の圧縮側の状況を示す。帯鉄筋方向の CFS の破断が断面のコーナー部で生じ，それが細い帯状に分 離している様子が示されている。

\section{PD 実験の結果と考察}

\section{1 地震時応答挙動}

(1) $0.2 \mathrm{~g}$ 相当

既存橋脚に対応する無補強の PD 45-N-1.5 に設計 想定地震である $0.2 \mathrm{~g}$ 相当の地震波を作用させた時の復 元力一応答変位の関係と載荷終了の 15 秒時におけるひ び割れ状況をそれぞれ図-7 (a), (b) に示す。最大応答 変位量は $\delta_{y}$ の約 1.7 倍の $23 \mathrm{~mm}$ であり,ひび割れは 曲げひび割れが観察できる程度で, 斜めひび割れやコン クリートの圧壊はみられず耐力の低下は生じなかった。 15 秒時の残存最大ひび割れ幅は, 柱付け根における 0.3 $\mathrm{mm}$ であった。この結果から, 設計想定地震に対して 既存橋脚が十分な耐震性能を保持していることを確認す ることができた。補強した PD 45-2 CF-1.5 の $0.2 \mathrm{~g}$ 相当加速度時での応答挙動も耐力の低下もなく健全であ り, 外見上の損傷はほとんどなかった。また, 最大応答 変位量は約 $1.4 \delta_{y}$ であり, PD 45-N-1.5 に比べて小さ いものとなった。

長短比が 3.0 の PD 40-N-3.0 の実験より得られた復 元力ー応答変位の関係と, 15 秒時のひび割れ状況をそ れぞれ図-8 (a)，(b)に示す。最大応答変位量は $\delta_{y}{ }^{\prime}$ の 約 2 倍の $25 \mathrm{~mm}$ となった。長短比 1.5 の供試体の場合 と同様に, 設計想定地震である $0.2 \mathrm{~g}$ 相当の加速度に対 して，大きな損傷はみられず耐力低下の生じない健全な 耐荷挙動を示した。補強した PD 40-CP-3.0も健全な 挙動を示し, 最大応答変位は PD 40-N-3.0 より小さ く約 $1.4 \delta_{y}^{\prime}$ の $17 \mathrm{~mm}$ であった。

図-9に PD 45-2 CF-1.5 と PD 20-CP-1.5 の時刻 歴応答変位の比較を示す。PD 20-CP-1.5 は実験の都 合により, 載荷は地震波の生起時刻の 7.94 秒で終了し ている。この 2 体の比較は, 帯鉄筋方向 CFS の 2 層目 の補強範囲がフーチング天端より $3 H$ の高さまでと 1 $H$ までとの違いによる影響を見たものであるが, 2 体の 応答変位挙動には顕著な差はなかった。

(2) $400 \mathrm{gal}$ 相当

作用地震波の最大加速度の大きさを, 設計想定地震加 


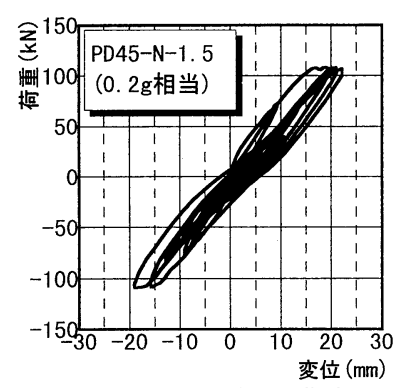

(a) 復元力-応答変位曲線

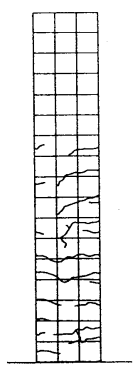

(b) ひび割れ状況

(15秒時)
図-7 PD 45-N-1.5 (0.2 g 相当)

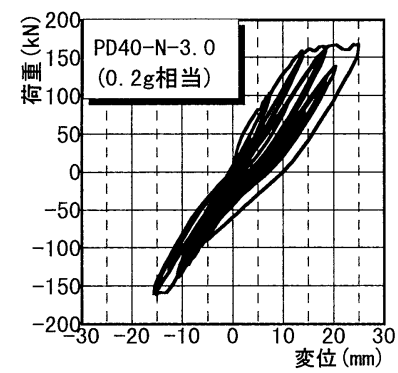

(a) 復元力-応答変位曲線 (b) ひび割れ状況

(15秒時)
図-8 PD 40-N-3.0 (0.2 g 相当)

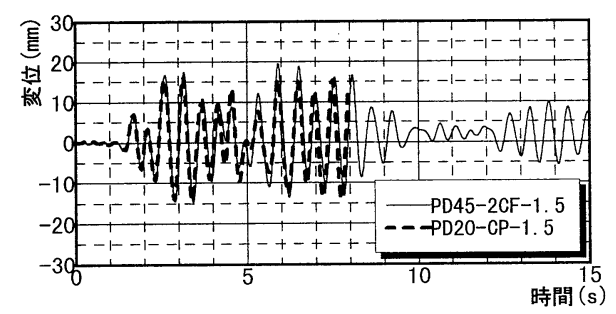

図-9 時刻歴応答变位曲線の比較 $(0.2 \mathrm{~g}$ 相当 $)$

速度の約 2 倍の大きさとなる $400 \mathrm{gal}$ 相当として PD 実 験を行った。図-10 (a), (b) に 1 回目の載荷実験にお ける APD 40-N-1.5 と補強した APD 40-CP-1.5の 復元力一応答変位をそれぞれ示し, 図-11には時刻歴応 答変位曲線の比較を示す。最大応答変位は両供試体とも ほぼ同じの $5 \delta_{y}$ 程度であり, 正側にドリフトした応答 挙動を示している。無補強の APD 40-N-1.5 は負側で 主鉄筋の座屈が生じ耐力が低下し, その後, 応答周期が 若干伸びた。APD 40-CP-1.5 は，ビデオの映像を見 ると柱付け根の CFS が膨らんだり元に戻ったりする様 子が見えたが, 実験終了後においてはコンクリートの剝 離などによる CFS の外見上の変化は見られず, 耐力の 低下は生じなかった。

振動のドリフトを考虑し, 正負それぞれの最大応答変

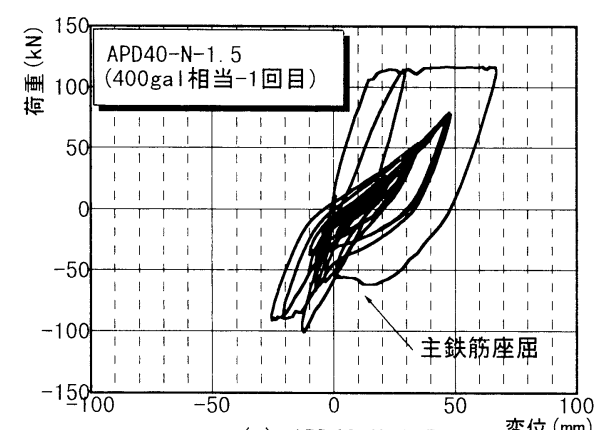

(a) $\mathrm{APD} 40-\mathrm{N}-1.5$

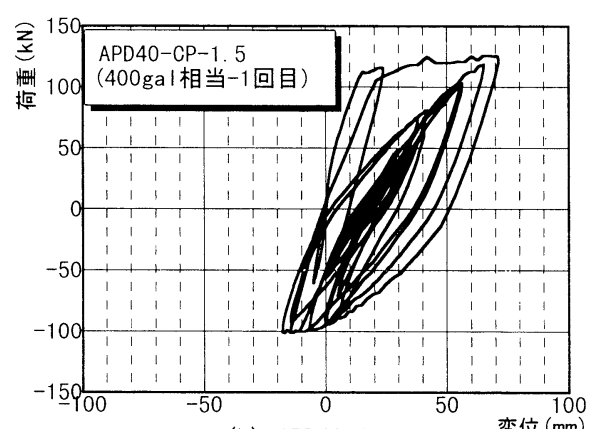

(b) APD40-CP-1.5 变位 $(\mathrm{mm}$

図-10 復元力 一応答変位曲線 $(400 \mathrm{gal}$ 相当 -1 回目 $)$

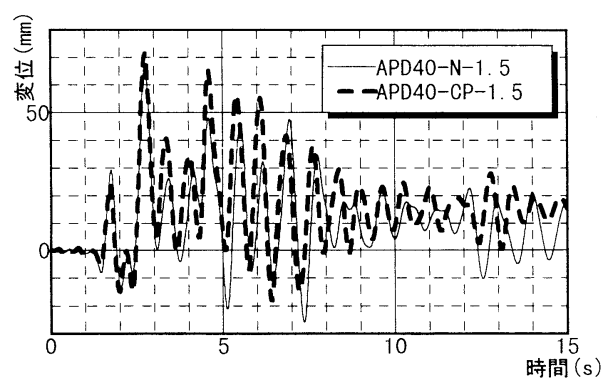

図-11 時刻歴応答变位曲線の比較 (400 gal 相当 -1 回目)

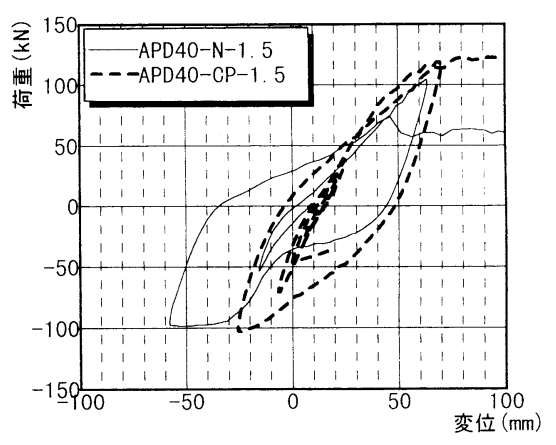

図-12 復元力一応答変位曲線の比較 (400 gal 相当)

位を足し合わせた值（以下，全振幅と記す）により応答 性状を見てみると，APD 40-N-1.5 の全振幅は 93 


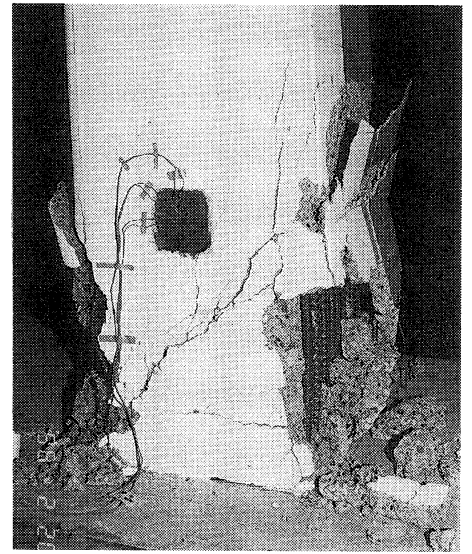

APD40-N-1. 5 (2.82秒時)

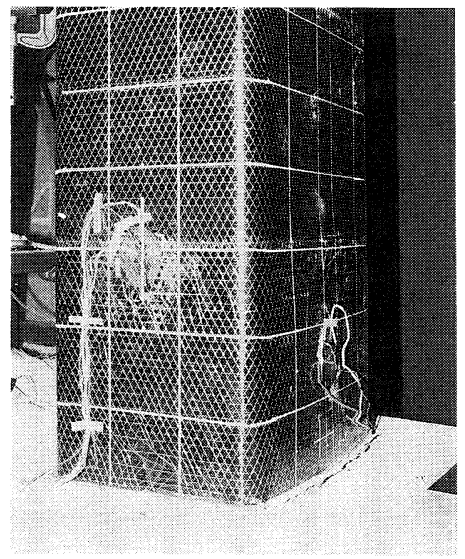

APD40-CP-1. 5 (2.71秒時)

写真-6 $400 \mathrm{gal}$ 相当 (2 回目) 載荷終了時の状況

$\mathrm{mm}, \mathrm{APD}$ 40-CP-1.5 のそれは $90 \mathrm{~mm}$ とほぼ同じと なった。400 gal 相当の地震力を受けた場合, 補強の有 無により耐力や外見上の損傷には大きな差が生じたが, 応答変位量としては同程度となった。

図-12 には, 2 回目の $400 \mathrm{gal}$ 相当の地震波が作用し たときの, 復元力一応答変位の比較を示す。実験途中, 応答変位量がアクチュエーターのストロークの容量以上 となったため, APD 40-N-1.5 は地震波生起時刻の 2.82 秒, $\mathrm{APD} 40-\mathrm{CP}-1.5$ は 2.71 秒の最大加速度の生 起時刻 2.55 秒を少し越えた当たりで載荷を終了した。 APD 40-N-1.5 は正負側（南北側）とも主鉄筋が座屈 し, 耐力も最大時の $1 / 2$ 程度まで落ち履歴挙動は逆 $\mathrm{S}$ 字 型を示している。一方, APD 40-CP-1.5 は負側（南 側）だけ主鉄筋が座屈し，履歴挙動は紡鍾形を保ってお り耐力の低下は見られない。補強が, 余震時の安全性に 関しても効果的であることがよくわかる。写真 -6 に最 終載荷時の状況を示すが, ST 実験の結果と同様に補強 の有無により損傷の程度はかなり異なったものとなって いる。

長短比 3.0 の供試体に $400 \mathrm{gal}$ 相当の地震波を入力し たときの時刻歴応答変位曲線の比較を図-13 に示す。な お, この場合は $0.2 \mathrm{~g}$ 相当の地震波による実験終了後に 同じ供試体に $400 \mathrm{gal}$ 相当の地震波を載荷したものであ る。無補強の PD 40-N-3.0 は, 地震波の生起時刻の 2.73 秒時には柱付け根部に斜めひび割れが確認でき, 2.74 秒時には正側で最大応答変位の $7 \delta_{y}$ 'を記録した。 最大応答変位を経験した後, 最初に変形が $0 \mathrm{~mm}$ 近く まで戻った 3.09 秒時には, 主鉄筋の座屈と共にコンク リートが大きく䟝離した。以後, コンクリートの劣化が 進行するにつれて応答は負側にドリフトし, 12.52 秒時 には負側での最大変位 $4.8 \delta_{y}{ }^{\prime}$ を記録し耐力は最大時の 約 70\% にまで低下した。補強した PD 40-CP-3.0 は

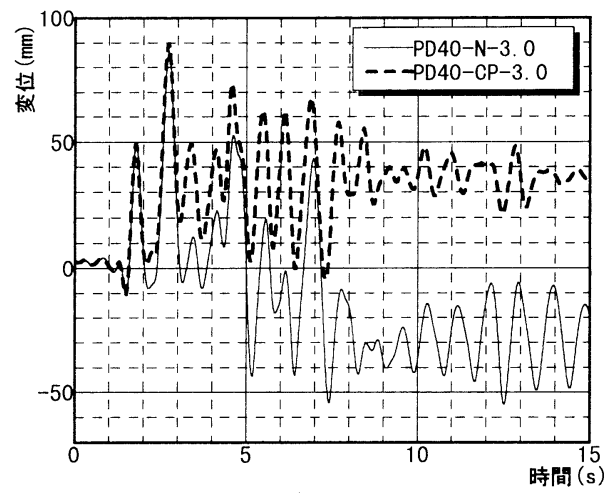

図-13 時刻歴応答変位曲線の比較 (400 gal 相当)

2.73 秒時に正側での最大変位となり, その值は $\mathrm{PD}$ 40-N-3.0 とほぼ同じの $7.3 \delta_{y}{ }^{\prime}$ となった。CFS の樹脂 部分に水平方向の亀裂が観察されたが, CFS の破断は 実験終了まで見られなかった。最大応答変位後, 最初に 変形が $0 \mathrm{~mm}$ 近くまで戻った 3.06 秒時にはフーチング 天端から $1 \mathrm{H}$ の高さの範囲で CFS が膨らみだし, 以後 の応答は正側にドリフトしたが耐力の低下は生じなかっ た。全振幅は PD 40-N-3.0で $140 \mathrm{~mm}$, PD 40-CP -3.0 で $100 \mathrm{~mm}$ となり, 長短比 1.5 の場合と異なり補 強したことにより全振幅が 70\%に低減された。このこ とは長短比の差が原因ではなく, 今回の $400 \mathrm{gal}$ 相当の 載荷は 2 回目の載荷であり, 供試体の損傷が大きく応答 変位量も大きくなったため, CFS の補強による効果が より発揮されたためと考えられる。

(3) $450 \mathrm{gal}$ 相当

図-14に $0.2 \mathrm{~g}$ 相当の地震波による実験終了後, 同じ 供試体に $450 \mathrm{gal}$ 相当の地震波を載荷して得られた復元 力一応答変位曲線の比較を示す。 $400 \mathrm{gal}$ 相当 2 回目の 実験と同様に両供試体ともアクチュエーターの容量を超 


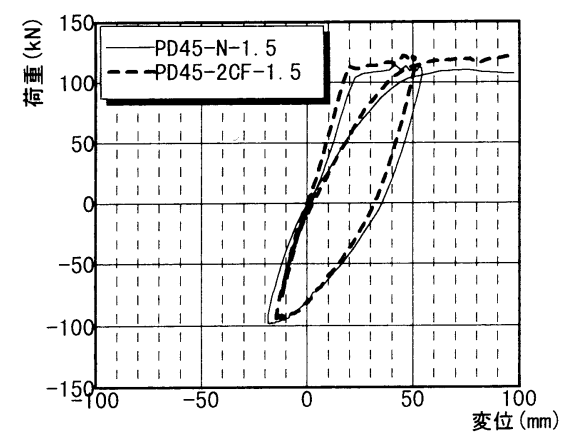

図-14 復元力一応答変位曲線の比較 (450 gal 相当)

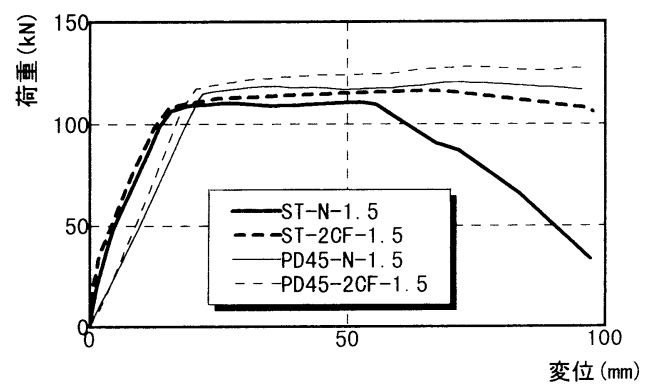

図-15 復元力一応答変位の包絡線の比較

える応答変位を示したため, PD 45-N-1.5 は 2.69 秒 時に, PD 45-2 CF-1.5 は2.70秒時にそれぞれ約 $7 \delta_{y}$ の変形が生じたところで実験が終了した。両供試体とも $\mathrm{ST}$ 実験の結果と異なり, 一方向のみに大きく変形した ため $7 \delta_{y}$ の変形まで耐力の低下は生じなかった。載荷 が終了する直前の 2.67 秒時には, PD 45-N-1.5 は柱 付け根部に斜めひび割れが大きく伸展していた。PD 45-2 CF-1.5 は長短比 3.0 の $400 \mathrm{gal}$ 相当の場合と同 様に柱付け根部の引張側で CFS の樹脂の亀裂が水平方 向に生じていたが, CFS の破断は見られなかった。こ の後, 各供試体の変位を $0 \mathrm{~mm}$ まで戻すと, $\mathrm{PD} 45-\mathrm{N}$ -1.5 は柱付け根部で主鉄筋が座屈し, かぶりコンク リートが剝離した。また, PD 45-2 CF-1.5 はフーチ ング天端から $1 H$ の高さの範囲で CFS が膨らみだし た。

図-15に図-14 の正側の包絡線とST 実験に使用した 供試体 ST-N-1.5 と ST-2 CF-1.5 より得られた荷重 一変位曲線の正側の包絡線の比較を示す。載荷速度の影 響9)により PD 実験で得られる最大耐力の值が ST 実験 での值より $10 \%$ 程度大きくなっている。また， PD 実 験での載荷が結果として偏載荷となったため, 無補強の 場合の ST-N-1.5 と PD 45- N-1.5 の包絡線の形状は かなり異なったものとなっている。これらのことは, 実 験によって得られる荷重一変位曲線は載荷速度または載 荷方法によって異なり, 特に, 主鉄筋の座屈やせん断破

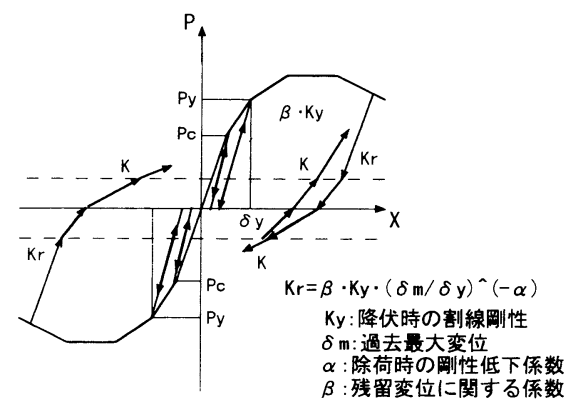

図一16 解析に用いた復元力モデル

壊により耐力が大きく変動する恐れのある場合には, 載 荷方法の相違の影響がかなり大きいことを示している。

\section{2 応答計算}

今回の解析に用いた復元力モデルを図-16 に示す。基 本的には通常よく用いられている鉄筋降伏後の除荷時剛 性を塑性率によって低下させる剛性低下型モデルであ る。特徴的な点としては, スケルトンカーブを多数の直 線で表し, 鉄筋降伏後の載荷と除荷時の剛性を低荷重域 とそれ以外とで変化させていることである。鉄筋降伏前 の載荷時の剛性は過去の最大変位へ向かう値, 鉄筋降伏 後の低荷重域以外における載荷時の剛性は過去の最大変 位の任意の倍数へ向かう值とした。復元力モデルの形状 の決定に際しては, ST 実験より得られた荷重一変位曲 線を参考にした。ただし, 主鉄筋の座屈による剛性の変 化は考慮していない。

図-17 (a), (b)にPD 45-N-1.5 と PD 45-2 CF1.5 の $0.2 \mathrm{~g}$ 相当の入力波による実験より得られた時刻 歴応答変位の結果と計算值の比較をそれぞれ示す。

図-18（a)，(b)には APD 40-N-1.5 と APD 40$\mathrm{CP}-1.5$ の $400 \mathrm{gal}$ 相当 1 回目の結果と計算值との比較 をそれぞれ示す。なお, 図中に示す計算值(2)とは, 載荷 速度の影響を考慮して復元力モデルの降伏耐力を $9.8 \mathrm{~N}$ 大きくしたモデルにより計算したものである。これらの 図に示されているように, 計算值(1)と(2)はほぼ同じ值を 示しており, 耐力がおよそ $10 \%$ 異なっても地震時の応 答変位挙動にはほとんど差のないことが確認できた。

$0.2 \mathrm{~g}$ 相当においては主鉄筋が座屈していないので, 実験值と計算值はよく一致している。主鉄筋が座屈し耐 力が低下した $400 \mathrm{gal}$ 相当においては, 座屈後応答のド リフトが生じ計算值はそれを表現できていないが, 応答 周期や曲線の形状はほぼ一致している。また, より正確 に地震時の応答变位挙動を求めようとするならば, PD 実験の結果より履歴挙動をモデル化するのも一つの方法 だと思われる。

\section{3 動的映像}

記録したビデオテープを標準再生することにより, 供 


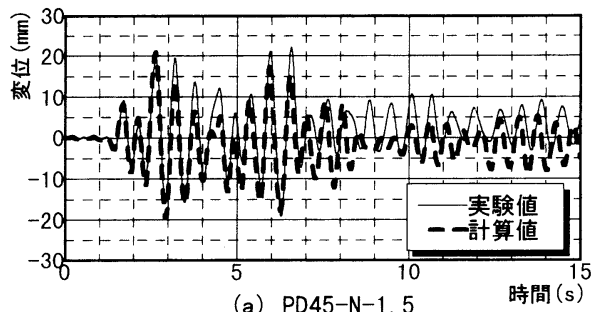

(a) PD45-N-1.5

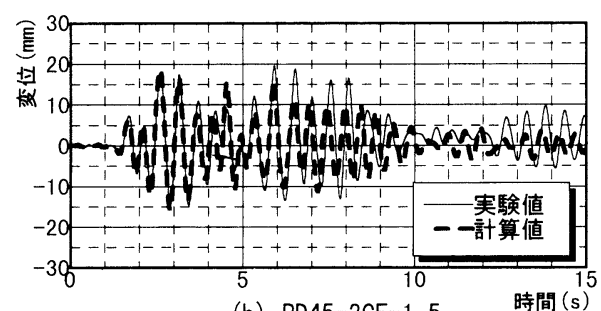

(b) PD45-2CF-1.5

図-17 時刻歴応答変位曲線 $(0.2 \mathrm{~g}$ 相当 $)$

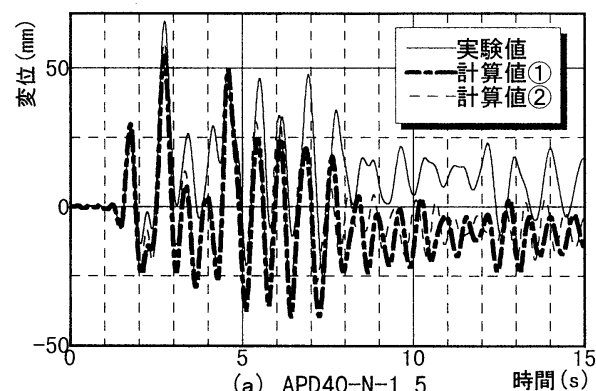

(a) APD40-N-1.5

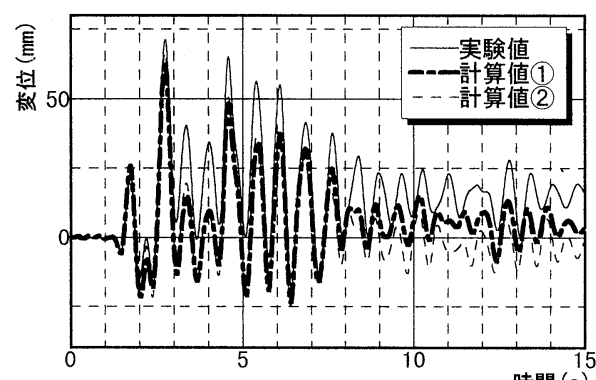

(b) APD40-CP-1.5

時間 (s)

図-18 時刻歴応答変位曲線 $(400 \mathrm{gal}$ 相当 -1 回目 $)$

試体の地震荷重下の挙動を実時間に即して見ることがで きた。その動的映像から, 曲げおよびせん断ひび割れが 瞬時に開閉する様子や, 主鉄筋の座屈やそれに伴いコン クリートが䟝離する様子, また, 損傷により変位応答が 正または負のどちらか一方に片寄ってしまう様子等を実 時間で観察することができた。特に，CFS で補強した 供試体において, 柱付け根部の CFS が柱幅全面にわ たって膨らんだり元に戻ったりする様子は顕著な特徵 で，鋼板巻立ての鋼板のように局部的な塑性変形するこ
となしに CFS が弾性的な挙動を示していることが，動 的映像から確認することができた。

\section{CFS の歪と拘束効果}

\section{1 載荷方向面での歪}

$\mathrm{ST}$ 載荷実験で得られた載荷方向面におけるフーチン グ天端から $1 H$ の高さの帯鉄筋と CFS の荷重一歪関係 を図-19 に示す。無補強の ST-N-1.5 の帯鉄筋の歪值 は最大耐力時で $400 \mu$ 程度であり, その後, 主鉄筋の座 屈とコンクリートの損傷により耐力が低下すると共に急 激に増加し, 最大で降伏歪近くの $1800 \mu$ 程度を示し た。CFS で補強した ST $-2 \mathrm{CF}-1.5$ の場合は, せん断 面での損傷がほとんどなかったため, 帯鉄筋に生じた歪 の值は小さく最大で $550 \mu$ 程度であった。また, CFS と 帯鉄筋の包絡線の大きさと形は似ており, 二つの歪值は 各荷重段階でほぼ同じ值となることが示されている。

長短比 3.0 の場合の比較を図-20に示すが, 全体的な 挙動としては長短比 1.5 の場合と良く似ている。ただ し, 無補強の AST-N-3.0 の帯鉄筋の歪值は, 柱付け 根部の損傷の状況が長短比 1.5 の場合と異なるため小さ く, 最大時で $650 \mu$ 程度であった。

図-21 には, ST-2 CF-1.5 と CFS の付着面積が $1 / 4$ となる AST-CPB-1.5 における CFS の歪值の比較を 示す。 $\mathrm{AST}-\mathrm{CPB}-1.5$ の歪值は $3 \delta y$ ぐらいから急激に 增加し, 最大值は ST $-2 \mathrm{CF}-1.5$ の 4 倍近くの $2000 \mu$ 程度を示している。付着面積が少ないことにより, せん 断面にひび割れが発生したものと推定される。

\section{2 載荷軸直交面での歪}

供試体 AST-CPB-1.5 の負側(南面)の幅中央におけ るフーチング天端から $H / 2$ の高さで測定した CFS の荷 重と歪との関係を図-22 (a), (b) に示す。水平方向の引 張歪は主鉄筋の座屈と共に急激に增大し, 最大で 6000 $\mu$ 程度を示した。この CFS は最終的にはコーナー部で 破断しており, 降伏歪から考えてコーナー部には膨らみ により曲げやせん断を含む複合的な力が作用していたも のと考えられる。縦方向の歪は主鉄筋の座屈とコンク リートの剥離などにより複雑な動きをしており, 值とし てはそれほど大きくならず引張歪で最大 $2800 \mu$, 圧縮 歪で最大 $2000 \mu$ 程度であった。

長短比 3.0 の供試体 AST-CP-3.0 の荷重之歪の関係 は長短比 1.5 の場合と同様な傾向であり, 測定された歪 の最大值は横方向で $5000 \mu$, 縦方向の引張歪で 2800 $\mu$ ，圧縮歪で $1200 \mu$ 程度となった。ただし, CFS は破 断していない。

図-23には PD 実験を行った PD 40-CP-3.0 の正側 （北面）の幅中央における高さ $0.3 H$ の位置で測定した CFS の縦方向の歪と時間の関係を示す。この供試体は 


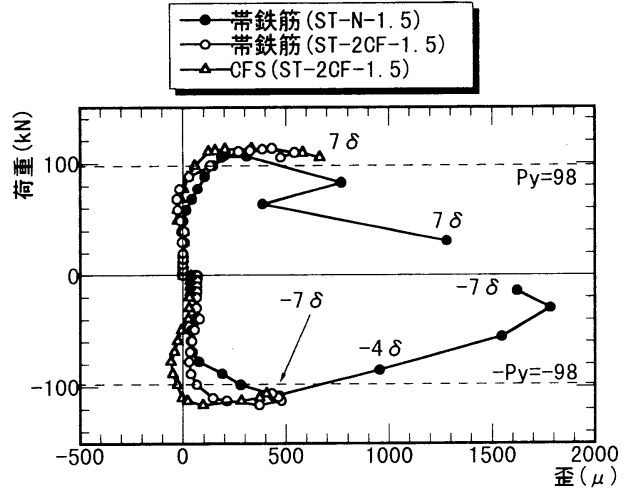

図-19 荷重と歪の関係（長短比 1.5 供試体）

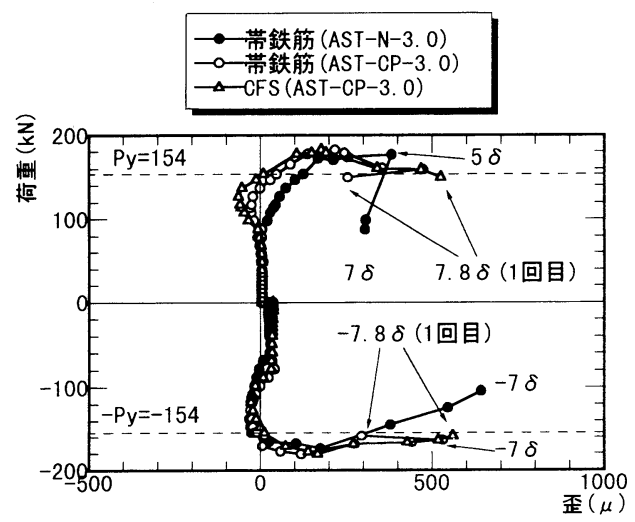

図-20 荷重と歪の関係（長短比 3.0 供試体）

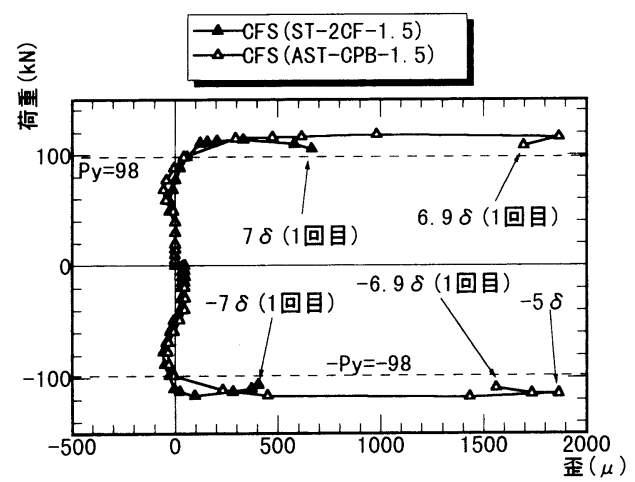

図-21 荷重と CFS の歪の関係 (ST-2 CF-1.5, AST-CPB1.5)

負側（南面）の主鉄筋のみが座屈し変位応答が正側にド リフトしたものであるが, ST 実験の場合とは異なり測 定された圧縮歪は大きく最大で $8500 \mu$ 程度を記録して おり, 変形のドリフト後 $2000 \sim 4000 \mu$ の間で変動して いる。長短比 1.5 の PD 45-2 CF-1.5 での $450 \mathrm{gal}$ 相 当の載荷時には, 供試体は正側のみに大きく変形したた め, 主鉄笳の座屈は生じず CFS の圧縮歪も正側で最大

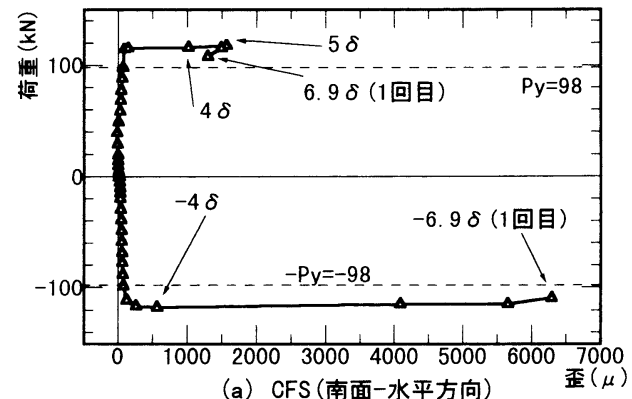

(a) CFS (南面一水平方向)

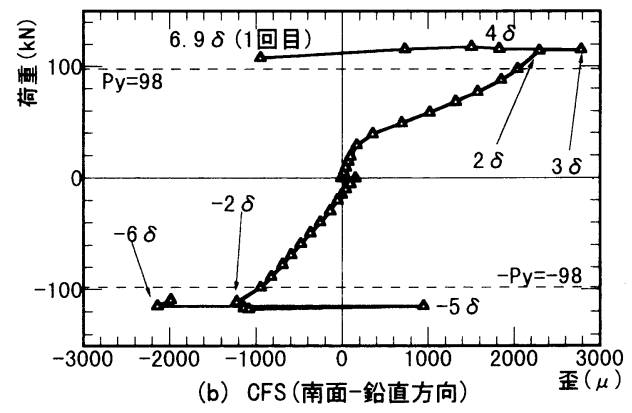

図-22 荷重と CFS の歪の関係 $(\mathrm{AST}-\mathrm{CPB}-1.5)$

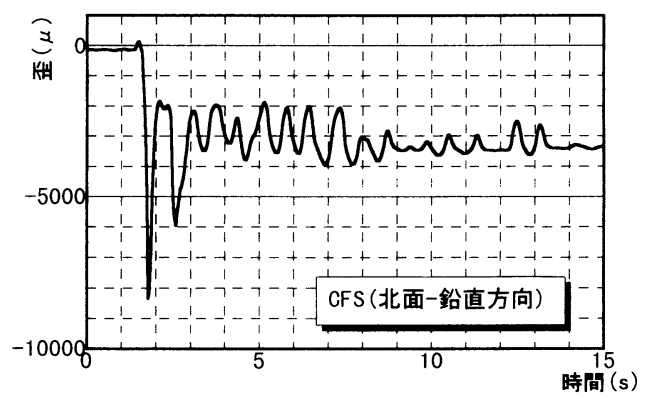

図-23 時刻歴歪曲線 (PD 40-CP-3.0 供試体 $-400 \mathrm{gal}$ 相当)

$12000 \mu$ 程度が記録されている。このように, CFS に 生じる圧縮歪の最大值は，供試体の受ける荷重履歴や破 壊形態および測定個所によって大きく異なるものであ り, 注意する必要がある。

歪の值から判断して, CFS による拘束効果が大きく 発揮され始めるのは主鉄筋の座屈などにより，かぶりコ ンクリートが膨らみだしたころからであり, CFS で囲 まれた内部のコンクリートが破壊し粉々になった状態に おいても，CFS による拘束は有効に作用していた。ま た, CFS とコンクリートの剝離は接着面で生じるので はなく, コンクリートの表面が薄く剝離して生じている ことを確認することができた。

\section{6. 結 論}

本研究より得られた結果をまとめると次のとおりとな る。 
（1）対象とした鉄筋コンクリート橋脚（既存橋脚） の変形性能の改良と䩚性の向上に CFS の巻立てによる 補強が有効であることを確認することができた。

（2）CFS の補強量を面積比で $0.1 \%$ とすることに より，既存橋脚の靱性率を 7 以上とすることができた。

（3）鞄性向上を目的とした場合の補強範囲として は, フーチング天端から $1 H(H$ : 断面高さ) の範囲が 重要であることが明らかとなった。

（4）断面の長短比 3.0 の壁式橋脚においても CFS の補強により変形性能は向上するが, その補強効果は長 短比 1.5 の場合と比べてやや低減した。

（5）供試体 ST-2 CF-1.5 と帯鉄筋方向の CFS と コンクリートとの付着面積がその $1 / 4$ である ASTCPB-1.5 の耐荷挙動はほぼ同じとなり，付着が勒性に 与える影響は小さいものであった。ただし，AST-CPB -1.5 の場合は終局時に帯鉄筋方向の CFS が破断した。

（6）既存橋脚は，設計想定地震の $0.2 \mathrm{~g}$ 相当の地震 波に対して，大きな損傷や耐力の低下など生じず十分な 耐震性能を保持していることが確認できた。

（7）面積比で $0.1 \%$ の CFS で補強することによ り，既存橋脚は設計想定地震の約 2 倍の $400 \mathrm{gal}$ 相当の 地震波に対して，大きな耐力の低下など生じず健全な耐 荷挙動を示すことが明らかとなった。また，余震を想定 した $400 \mathrm{gal}$ 相当 2 回目の載荷においても耐力の大きな 低下は見られず，CFS による補強が余震時の安全性の 確保においても有効であることが示された。

（8）CFS で補強することにより, 終局時の部材の 損傷箇所は限定され，かつ，その損傷範囲は無補強の部 材と比べて小さくなった。

（9）実験により得られる部材の履歴挙動は載荷方法 によって異なり，特に，主鉄筋の座屈やせん断破壊が生 じ耐力が大きく変動する部材は，その影響を大きく受け ることが示された。

（10）応答計算の結果，歪速度による降伏耐力の 10 $\%$ 程度の上昇は, 地震時の変位応答挙動に影響を及ぼ さないことが確認できた。

(11) 動的映像から, 主鉄筋の座屈により CFS が膨 らんだり元に戻ったり弾性的に挙動することを顕著に観 察することができた。CFS の局部的な塑性変形は見ら れなかった。

(12） 帯鉄筋方向の CFS は柱幅中央部よりコーナー 部で先に破断することが確認できた。

（13）各供試体において測定された CFS の最大圧縮
歪は 1000 12000 $\mu$ と広い範囲にわたっており，その 值は供試体の受けた載荷履歴や破壊形態および測定個所 で大きく変動することが示された。

［謝 辞］本研究を実施するに当たり，横浜国立大学 土木工学教室の森下豊技官, 原山到君（現 愛知県庁） ならびに大学院生の辻昌宏君に参加協力を得た。また, 大谷祥三氏（現 日本道路公団 室蘭工事事務所所長） と大川征治氏（日本道路公団 東京第一管理局技術部調 查役）に多大の御支援を賜るとともに，桑田直樹氏（馬 淵建設（株)），小林朗氏（東燃（株)），原島弘氏（大成 サービス (株)）をはじめとする関係各位に御協力を得 た。ここに感謝の意を表します。

\section{参 考 文 献}

1）宇治公隆：シート状連続炭素㵶維補強材を用いた既設鉄 筋コンクリート部材のせん断耐力向上効果に関する研 究, コンクリート工学論文集, Vol. 3, No. 2, pp. 37〜 47, 1992. 7

2）岡島豊行 - 勝俣英雄 - 石田 博 - 東田典雅 : 炭素緘維に よる既存 $\mathrm{RC}$ 橋脚の耐震補強（その 2 載荷実験）, 土 木学会第 45 回年次学術講演会講演概要集, 第 5 部, pp. 824 825, 1990. 9

3) 藤原 博・東田典雅・大野 了・岡島豊行：炭素㵶維に よる $\mathrm{RC}$ 橋脚の耐震補強効果について（その 1 載荷実 験), 土木学会第 46 回年次学術講演会講演概要集, 第 5 部, pp. 770 771, 1991. 9

4）山口隆裕・武村浩志・柳井修司・池田尚治 : 鉄筋コンク リート柱の耐震性能とその動的挙動, コンクリート工学 年次論文報告集, Vol. 16, No. 2, pp. 1265 1270, 1994

5) 酒井伸治・遊佐和明 - 柳 武夫 - 吉田光秀 : RC 2 径間 連続箱析橋の補強工事, プレストレストコンクリート, Vol. 37, No. 6, pp. 33 41, 1995. 11

6) 柳井修司・山口隆裕・池田尚治 : 鉄筋コンクリート 2 層 ラーメンにおける地震応答の動的映像化実験, コンク リート工学年次論文報告集, Vol. 17, No. 2, pp. 481〜 486, 1995

7）宇治公隆：シート状連続炭素緘維による鉄筋コンクリー 卜構造物の補強ならびに耐久性向上に関する研究, 横浜 国立大学博士論文, 1993. 3

8）池田尚治・山口隆裕・鵜澤哲史 : 鉄筋コンクリート柱の 地震時挙動と耐震設計の評価, コンクリート工学論文 集, Vol. 2, No. 1, pp. 105 114, 1991. 1

9）山口隆裕・武村浩志・平 陽兵・池田尚治 : 鉄筋コンク リートの準動的地震応答実験における歪速度および粘性 減衰の影響, コンクリート工学論文集, Vol. 7, No. 2, pp. $143 \sim 155,1996.7$

10）日本道路協会：道路橋示方書 - 同解説 $\mathrm{V}$ 耐震設計編, 1990. 2

（原稿受理年月日 : 1996 年 7 月 10 日） 


\section{Seismic Behavior of Reinforced Concrete Piers \\ Strengthened with Carbon Fiber Sheets}

By Koji Osada, Shinya Ohno, Takahiro Yamaguchi and Shoji Ikeda

Concrete Research and Technology, Vol. 8, No. 1, Jan. 1997

Synopsis In order to certify the effect of the strengthening with carbon fiber sheets on the improvement of ductility of the reinforced concrete piers and to investigate the seismic properties after strengthening, static and pseudo-dynamic tests using reinforced concrete column specimens were carried out. From the experimental results, it was verified that the ductility of the piers can be improved by strengthening with carbon fiber sheets, and adequate volume and the necessary area of the carbon fiber sheets for the strengthening were obtained. Also, it was shown that the rupture of the carbon fiber sheets of the horizontal direction was occurred first at the corner of the column. From the results of pseudo-dynamic tests, it was confirmed that the piers strengthened by carbon fiber sheets could maintain well under the earthquake which had the maximum acceleration of $400 \mathrm{gal}$.

Keywords : seismic strengthening, carbon fiber sheet, reinforced concrete pier, ductility, pseudo-dynamic test 